\title{
Our "Shrinking" Farmland: Mirage or Potential Crisis?
}

\author{
CLIFTON B. LUTTRELL
}

E ACH year, more American farmland is being converted to nonfarm uses such as highways, houses, airports, and shopping centers. This development has engendered fear that the decline in farmland will eventually produce a severe crisis for U.S. food production.

A recent study, in which 11 U.S. government agencies participated, stated: "Every day in the United States, four square miles of our nation's prime farm lands are shifted to uses other than agriculture. The thief is urban sprawl. . . Ten years from now, Americans could be as concerned over the loss of the nation's prime and important farm lands as they are today over shortages of oil and gasoline."1

Leading proponents of the shrinking farmland thesis contend that decisions to convert agricultural land to

1Where Have the Farmlands Gone? (Washington, D.C.: National Agricultural Land Studies, September 1979), pp. 1-2. Similar views were expressed in The Farm and The City (The American Assembly, Columbia University, April 10-13, 1980), and in Erick P. Eckholm, Losing Ground: Entironmental Stress and World Food Prospects (New York: W. W. Norton and Company, Inc., 1976), pp. 183-86. nonagricultural uses should be transferred from the private to the public sector. Michael Brewer states: "Each choice [by individual farmers to sell farmland to developers] may be sensible in its own context. But, collectively, they reduce the country's capacity to produce food, fiber, and wood." He argues: "The first step is to 'find out' . . . what tools are available to local, state and Federal governments to deal with it." Lester Brown concludes: “. . . it [cropland] can be protected from competing nonfarm demands only through land use planning."

In contrnst to these views, this article asserts that the arguments for social planning of land use are erroneous. First, there is no evidence that the quantity of cropland is shrinking or that shortages of food are imminent. Furthermore, even if the alleged problem did exist, there is no evidence that it could be solved more efficiently by social planning than by market participants.

Where Have the Farmlands Gone?, p. 6.

3 Ibid., p. 14. 


\section{Some Arguments for Social Land Use Planning}

A nember of individials and groups have expressed concern about the quantity of pime farmland that is being dverted from agricultural uses. Secretary of Agriculture Bob Bergland stated 4 allure to protect our agnoulture and the natural resources on which it depends will pet us on a collision course with disaster " Fomer Secretary of Agriculture Earl Butz wamed the nation that the loss of farmland to ubanzation uses could spell trotble for our food supplies: If USDA'S projections hold true, the consequences of fallure to stem the Sirinkage of $\mathrm{U} S \mathrm{~S}$ farmland will be ominous for the American economy 2 the Amercan Land Forum, in calling for a tion to protect fam lands from further los, stated. 4 , decisions about agricultural lands are actually beng made now, at a time when the erucial inportance of the resource, is practically 070 ibible to the average citizen 8 In addL tion to theif concen for food production, critics of crop land conversion to urban uses see other social costs, induding a degraded environment, impaired water quality, lost wildife habltat, and diminished beauty of landscapes 4 David Berry and Thomas Plaut likewise onsider the loss of scente qualities an addi tional cost of unbanization of fammland 5 :

Rupert Gutler stated Many othenwise politically aggressive Americans seem lo dam up, look the other way or change the stbjed whenever its suggested that the pablic's stake in private land use decistons has been inadequately protected.

Hasn the time come for a comprehensive effort by loeal governments, aided by state and Federal agencies, to preserve some of these traditions, in a democrate way, through the use of local land use plans approved by local peopleps

There Have the Farmlands Gone? (Washington, $\mathrm{D}, \mathrm{G}$. National Agticultural Land Studies, September 1979), 13

${ }^{2} \mathrm{Carl}$ Butz, An Economic Analysis, US Famland Shrinking New York Journal of Commerce (October: 16, $1970 \%$

3 Where Have the Farmlands Gone? p. 14.

4 ibid, p. 10 .

5 Daxid Beny and Thomas Plaut, Retaning Agricultural Activities Under Urban Pressure. A Review of Land Use Conflicts and Policies," in Folicy Sclences (Ansterdan, Elseview Publishing Company, 1978), p, 160.

Where Have the Farmlands Gone, p. 20 .

\section{Implications of "Shrinking Farmland Problem"}

Several implications are immediately suggested by claims that there is a shrinking farmland crisis. First, and most obvious, is the contention that the quantity of farmland is declining. Second, if the amount of such land actually is declining, this fact should be reflected in the relative price of farm products and food. Unless offset by other factors of production, a constant or rising demand for food coupled with a declining quantity of prime cropland would lead to declining farm production and rising farm commodity and food prices relative to prices of other products. Finally, if food is becoming more scarce relative to nonfood products, given a relatively inelastic demand for food (a one percent change in the supply of farm products results in a larger than one percent change in price), a rising proportion of disposable personal income (personal income after taxes) would be spent on food. In other words, with a fixed relationship between land and farm production, a reduction in the real quantity of cropland with a constant or rising demand for food leads to rising farm product and food prices, higher real food costs, and a smaller percent of personal income available for nonfood purchases. Although, all of the above would be implied if a shrinking farmland crisis actually existed, none of these events is consistent with the data.

\section{Quantity of Cropland Difficult to Measure}

As Theodore W. Schultz noted, economic analysis of land is not a simple matter. "Land as an economic variable is exceedingly hard to get at. . . . The fact that land is open and aboveboard, physical and concrete, and legally divided into neat, carefully described parcels or lots ... does not help one determine the supply of land."

In the early 1800 s, economists such as Thomas Malthus and David Ricardo considered the contribution of land to food production to be relatively fixed and concluded that the real value of food would inevitably rise along with population growth, eventually necessitating the use of poorer land, more machines, and more labor to produce additional food. Consequently, food prices and rent would rise relative to other prices. ${ }^{6}$ While this view recognized that cropland did not refer to a fixed number of acres, the potential real output of the land was assumed to be predetermined and relatively fixed. ${ }^{6}$ It is now recognized that

${ }^{4}$ Theodore W. Schultz, The Economic Organization of Agricultute (New York: MoGraw Hill Book Company, Inc., 1953) p. 145.

5avid Ricardo, The Principles of Political Economy and Taxation, ed. Ernest Rhys (New York: E. P. Dutton and Co, Inc., 1948), p. 280; and Thomas Robert Malthus, On Population (New York: The Modern Library, published by Random House, 1960), pp. 12, 13, 32, and 33 .

GDavid Ricardo, The Principles of Political Economy and Taxation, pp. 80-81. For a discussion of classical views, see Harry G. Johnson, Theory of Income Distribution (London: Gray-Mills Publishing Ltd., 1973), p. 74. 


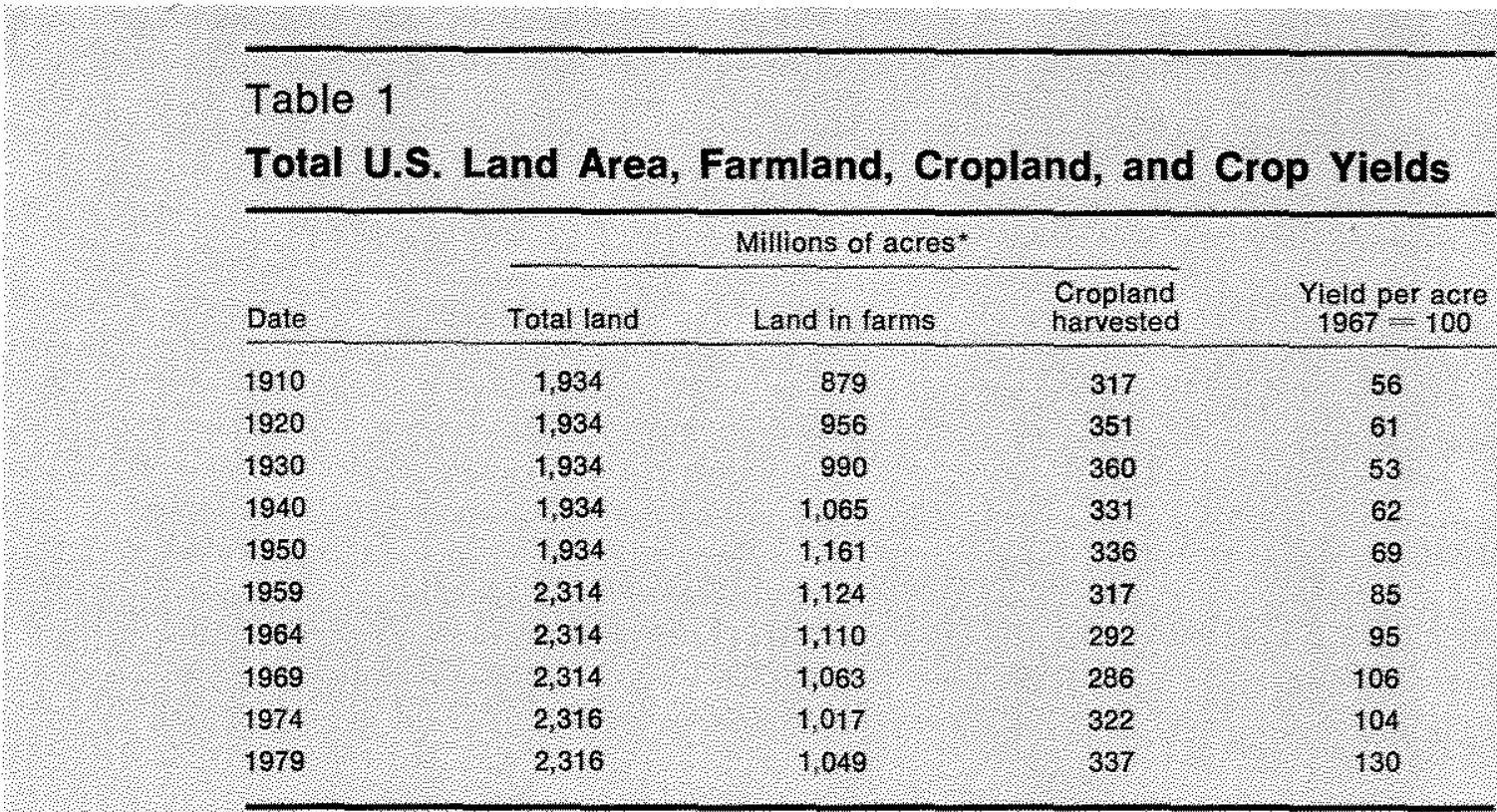

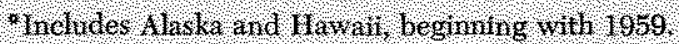

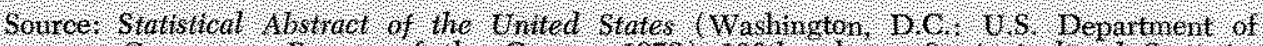

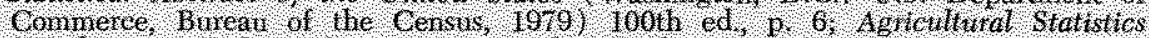

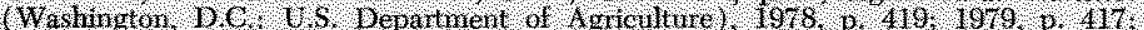

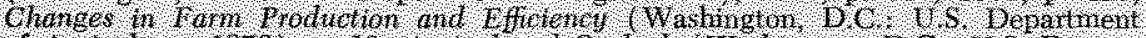

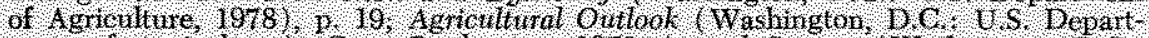

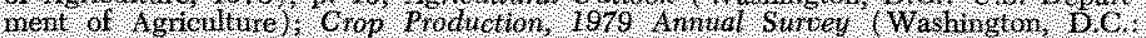
US. Department of Agriculture, Janiary 1980 ).

the surface area that can be used for crops is more variable than Malthus and Ricardo thought and that output per unit of surface area is likewise more variable.

\section{Acres of Cropland Variable but Increasing}

Despite the difficulty of estimating the amount of cropland, it is now evident that the amount is not fixed. Rather, the quantity actually in use at any given time depends on a number of factors.

Because new technology reduces land development costs and/or increases crop yields, thus providing favorable returns on the investment, land areas currently used for other purposes can be developed into profitable cropland. As Martin Bailey noted: “. . . mountainous land good only for grazing could be leveled and made arable, and marshy lands, lake bottom and the fringes of the ocean could be filled to make arable land." Examples of such conversion in the U.S. include the Imperial Valley in California, which was irrigated and developed into cropland,

Tartin J. Bailey, National Income and The Price Level (New York: MoGraw Hill Book Company, Inc., 1962), p. 111. and the Obion River Valley in Tennessee, much of which was developed into cropland through construction of a drainage system. Further, although there is a vast amount of acreage (such as grazing, range, or forest land) that is not currently used for cropland at present prices, this acreage could be converted to crop production within a short period of time if it was profitable to do so. If the net return on an acre of land is greater when used for crop production than when used for grazing, it will be used for crops. Conversely, if the expected net return on land is greater when it is used for purposes such as grazing, forestry, etc., the land will be used for these purposes.

As shown in table 1, only a small portion of the U.S. land area is currently used for crops. Of the 2.3 billion acres of land in the nation, only about 40 percent is farmland and less than one third of this farmland has been actually used for crop production. Hence, a large amount of land area is available for conversion to or from crop production.

Data on cropland harvested indicate that sizable changes have occurred during the past 80 years in terms of the land area used for crop production. Acres 
Table 2

\section{Changes in Cropland Harvested and Selected Prices (Annual Rates)}

\begin{tabular}{|c|c|c|}
\hline & $1950-69$ & $1969-79$ \\
\hline Acres harvested: & -0.8 & 17 \\
\hline Prices received by farmers: & 0,2 & 8.5 \\
\hline Price of hdustrial commodities & 16 & 83 \\
\hline GNP price detfator & 2.6 & 6.7 \\
\hline Consumer price index (all items) & 2,2 & 71 \\
\hline $\begin{array}{l}\text { Producer orice index } \\
\text { (Inished goods) }\end{array}$ & 1,6 & 7.3 \\
\hline
\end{tabular}

Source Economic Repont of the President (Washington, D.C. United States Gevernment Printing Office, 1980), pp. 208, 259,265, 268, 312, Changes in Farm Production and Effolencl, (Washington, D.C., US, Department of Agriculture, 1978 ), p, 19 .

harvested rose from 317 million in 1910 to a peak of 360 million in 1930 . By 1969 , acres harvested had declined to 286 million but increased again in the $1970 \mathrm{~s}$ and rose to 337 million in 1979. Although government production control and crop diversion programs reduced the acreage of some crops harvested from 1934 through 1974, the effectiveness of these programs in terms of total crops harvested can be overemphasized since production of uncontrolled crops on diverted acres was permitted in most years. Furthermore, the impact of these production controls has been sharply reduced since 1969 .

The change in acres of crops harvested has been positively correlated with the change in farm product prices relative to other prices. For example, when the cropland acreage was declining $(0.8$ percent per year during the two decades, 1950-69), the index of prices received by farmers declined relative to other prices (table 2). During this same period, farm commodity prices rose only 0.2 percent per year -1.4 percentage points less per year than the prices of industrial commodities or the producers price index, 2 percentage points less than the consumer price index, and 2.4 percentage points less than the GNP price deflator. During 1969-79, however, when the number of acres of crops harvested was rising, prices received by farmers rose at a slightly faster rate than most other prices. For example, during the 1969-79 decade, farm prices rose at an annual rate of 8.5 percent per year, compared with 8.3 percent for industrial commodities and less than 8 percent for each of the other series.
This relative increase in farm prices provided farmers with sufficient incentive to convert additional land to crop production.

The increase in farm product prices relative to other prices during 1969-79 is not an indication of potential famine either in the U.S. or abroad. Rather, it represents a rise in export demand for U.S. farm products, attributable primarily to a gradual reduction in foreign trade restrictions (that began prior to World War II) and to the large volume of U.S. currency accumulations abroad (resulting from U.S. petroleum imports following the sharp increase in petroleum prices). ${ }^{8}$ The U.S. farm sector, having a comparative advantage in production of farm products (it is relatively cheaper in terms of resources used to produce farm products in the U.S. than in other countries), exported an increasing proportion of total farm output.

\section{Yields Per Acre Rising}

While output per acre of cropland varies from year to year as a result of weather and other short-rum factors, the sharp increases in crop yields over the longer run indicate that yields are sensitive to other factors of production such as technology and prices. The development of new technology and/or a change in the price of crops relative to the cost of farm inputs leads to a change in output per acre. For example, new technology that reduces the real cost of fertilizers, improves insect and plant disease control, and provides improved seeds increases output per acre and, consequently, has the same impact on output as an increase in the acreage of farmland. In essence, the increase in farmland "quality" produces the same result as an increase in quantity. Similarly, an increase in the price of crops relative to the returns on land from alternative uses provides farmers with incentive for using more yield-increasing factors (e.g., greater quantities of fertilizer) per acre, as well as for using more acres of land for crop production. With the increase in the value of farm products in the early 1970 s as a result of rising foreign demand, greater quantities of yield-increasing inputs were added to cropland; consequently, yields increased as did the number of acres harvested.

The use of yield-increasing factors caused average corn yields to rise from 70 bushels per acre in the three years, 1964-66, to 100 bushels per acre in 1977 79 , despite the increase in acres harvested during the

8See Clifton B. Luttrell, "Rising Farm Fxports and International Trade Policies," this Review (July 1979), pp. 3-10. 
Table 3

\section{Rates of Change of Selected Prices, Per Capita Personal Income, Percent of Personal Income Spent on Food, and Percent of Farm Commodity Sales Exported and Imported}

\begin{tabular}{|c|c|c|c|c|}
\hline & $1950-60$ & $1960-70$ & $1970-79$ & $1950-79$ \\
\hline \multicolumn{5}{|l|}{ Prices - rate of change: } \\
\hline Recelved by farmers (USDA) 1 & $-0,8$ & 1.5 & 9.1 & 3.0 \\
\hline Food $(\mathrm{CPl})$ & 1.7 & 27 & 8.2 & 4.0 \\
\hline All commoditles less food (CPI) & 1.4 & 10 & 6.3 & 3.1 \\
\hline$A l s e r v c e s(\mathrm{CP})$ & 3.6 & 3.8 & 76 & 49 \\
\hline Industrial commodities (PPI) 1 & 2.0 & 1.4 & 8.9 & 3.9 \\
\hline $\begin{array}{l}\text { Disposable personal income per capita } \\
\text { (rate of change) } 2\end{array}$ & 3.6 & 5.6 & 9.2 & 6.0 \\
\hline \multirow{2}{*}{$\begin{array}{l}\text { Percent spent on total tood } 2 \\
\text { tood at home }\end{array}$} & $22.4-20.2$ & $202-17.3$ & $17,3-16,6$ & $224-166$ \\
\hline & $178-161$ & $16.1-134$ & $13.4-12.5$ & $178-125$ \\
\hline \multicolumn{5}{|l|}{ Peroent of total tarm commodity sales. } \\
\hline Exporteds & $101-14,1$ & $14,1-14,6$ & $146+24.8$ & $101-24,8$ \\
\hline Imported & $14,0-111$ & $111-114$ & $114-126$ & $140-12.6$ \\
\hline
\end{tabular}

1 Economic Report of the President (Washington, D, C, US, Govemment Printing office, 1979), pp, 240, 248, 290, Economic Indicators (Washington, D.C. U.S. Department of Agriculture, 1980), CPI (Consumer Erice Lidex), and PPI (Producet Price Index)

National Food Review (Washingtom, D.C, U.S, Department of Agreulture, Winter 1980), pp, 6, 56, and Economio Indicators.

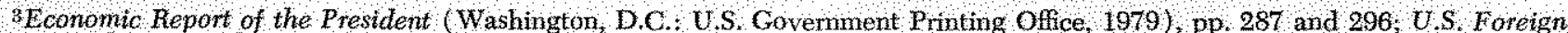
Agricultural Trade statistical Report (Washington, D.C. U.S. Department of Agriculture, 1970), p. 2, Agricultural Outlook (Waskington, D.C. U.S. Department of Agriculture).

latter period." As shown in table 1, the trend rise in crop yields is not limited to corn. Yields of all cropland harvested rose from an average index of 83 in $1957-59$ to 123 in $1977-79$, an increase of 48 percent. Furthermore, there is no indication that a slowing has occurred in the trend growth of crop yields. From 1967-69 to 1977-79, crop production per acre rose at a 1.7 percent rate, well above the 1.1 percent rate of increase from 1910 to 1969.10

\footnotetext{
${ }^{9}$ Agricultural Statistics (Washington, D.C.: U.S. Department of Agriculture, 1979), p. 30; and Agnicultural Outlook (Washington, D.C.: U.S. Department of Agriculture, May 1980), p. 33 .

${ }^{10} \mathrm{~A}$ rate of yield growth higher than that of 1969-79 was realized only in the decade of $1950-60$, when output per acre rose at a 2.6 percent rate. During the 1950 mo decade however, the number of acres harvested declined sharply indicating that less fertile acres were taken out of crop production.

A number of recent studies point to a possible decline in the rate of growth in erop yields in the years ahead. Agricultural Production Efficiency (Washington, D.C.: National Academy of Sciences, 1975 ), p. 195. This study concluded that biological realities suggest a slowing of the rate of increase in productivity for most crops. Yoa-chi Lu, Philip Cline and Leroy Quance, Prospects for Productivity Growth in U.S. Agriculture (Washington, D.C.: U.S. Department of Agri-
}

\section{Shrinkage Not Indicated by Relative Prices of Food}

During the period, $1950-79$, farm product prices rose at a slower rate than other major price series and only half as fast as disposable personal income (table 3). Consequently, the proportion of disposable personal income spent on food declined from 22.4 percent in 1950 to 16.6 percent in 1979.

During the more recent decade, 1970-79, farm product prices rose somewhat faster than prices of most nonfarm products. Farm prices rose at a 9.1 percent rate, slightly faster than the 8.9 percent rate for in-

culture September 1979). The authors expressed doubt that agricultural productivity growth through the year 2000 will equal the historical rate unless research and extension invest. ment increase and unprecedented technologies develop.

On the other hand, Glen L. Johnson contends that agriculture has a high long-run supply elasticity in The Overproduction Trap in Agriculture, ed. Glen L. Johnson and Leroy Ouance (Baltimore: The Johm Hopkins University Press, 1972 ), pp 20 and 183. Furthermore, he argues that if demand (for farm products) was doubled or tripled, we would have so much money invested in land that earnings would not cover acquisition costs. 


\begin{tabular}{|c|c|c|}
\hline \multicolumn{3}{|c|}{$\begin{array}{l}\text { Rates of Change of Specified Prices, Per Capita Personal } \\
\text { Income, Percent of Personal Income Spent on Food, } \\
\text { and Percent of Farm Commodity Sales Exported and Importe } \\
\text { in the First and Second Hall of the } 1970 \text { s. }\end{array}$} \\
\hline$\sqrt{3}$ & 197075 & $1975-79$ \\
\hline \multicolumn{3}{|l|}{ Prices - rate of change? } \\
\hline Recaived by farmers (USDA) & 11.0 & 68. \\
\hline Food (CPl) & 8.8 & 7.5 \\
\hline All conmoditles less food (CPI) & $5: 8$ & 70 \\
\hline Al services (CPI) ? & 6.5 & 89 \\
\hline Industrial commodities (PPI) & 9.3 & 8.3 \\
\hline \multicolumn{3}{|l|}{$\begin{array}{l}\text { Disposable personal heome per capita } \\
\text { (rate of change) }\end{array}$} \\
\hline Percent spent on: total tood & $17.0-17.0$ & $17.0-16: 6$ \\
\hline tood at home & $13.4 \div 13.0$ & $13.0-12.5$ \\
\hline \multicolumn{3}{|l|}{ Percent of total farm commodity sales? } \\
\hline Exported & $1 4 . 6 \longdiv { 2 5 . 2 }$ & $25.2-24.8$ \\
\hline Imported & $11.4=10.6$ & $10.6-12.6$ \\
\hline
\end{tabular}

dustrial commodities, and well above the rate of in crease for all commodities (less food) and for all services. The relative increase in farm product prices during this decade, however, was related to a sharp increase in demand for U.S. farm products, primarily for export, rather than to a shrinkage in cropland. (There is no evidence that farmland conversion to urban uses was greater in 1970-79 than in any other post-World War II decade.) Exports started rising in the $1950 \mathrm{~s}$, rose moderately in the $1960 \mathrm{~s}$, and accelerated sharply in the 1970s. For instance the rate of increase was relatively low in the $1950 \mathrm{~s}$ and the $1960 \mathrm{~s}$, and exports totaled only 14.6 percent of sales in 1970 . However, exports accelerated from 14.6 percent of total sales in 1970 to 25.2 percent in 1975 (table 4). Furthermore, sharp increases in farm commodity exports were not offset by rising imports of farm commodities. Farm commodity imports declined from 11.4 to 10.6 percent of sales of farm products during the period.

By 1975 , farm commodity exports as a percent of sales had leveled of, and farm commodity prices began to decline again relative to other prices (table 4). From 1975 to 1979 , farm commodity prices rose at the rate of 6.8 percent, 2.1 percentage points less than the rate of increase in the price of all services and 1.5 percentage points less than the price of industrial commodities. The price of food, which had increased at about the same rate as disposable personal income in the first half of the $1970 \mathrm{~s}$, rose 2.2 percentage points slower in the second half of the decade than did disposable personal income.

As indicated earlier, much of the increase in farm exports since the mid-1950s can be attributed to a gradual reduction in foreign trade restrictions, which had been almost prohibitive following the SmootHawley Tariff Act of 1930. A number of major reductions in average ad valorem rates have been negotiated since the 1947 General Agreement on Tariffs and Trade; numerous studies show that these reductions have a major impact on trade. ${ }^{11}$ However, reductions in tariff duties do not increase trade imme diately, as evidenced by the gradual rise in exports during the $1950 \mathrm{~s}$ and $1960 \mathrm{~s}$. Part of the sharp increase in exports during the early 1970 s may be attributed to the implementation of monopolistic petroleum policies by the OPEC nations, which resulted in a sharp increase in dollar accumulations abroad and the dollar's reduced value in terms of foreign currencies.

Despite the accelerating export demand for U.S. farm products, however, the farm sector concurrently produced enough food to maintain relatively stable

\footnotetext{
11See Clifton B. Luttrell, "Rising Fam Exports and International Trade Policies," pp. 6-7.
} 
real prices for food in the U.S., further reducing the proportion of disposable personal income spent on food.

\section{Little Basis for Cropland Preservation Plans}

Considering the facts that cropland acreage is not shrinking, crop yields have increased, and food costs as a percent of personal income have declined, allegations of a "shrinking" farmland appear to be unfounded. Consequently, the arguments for developing comprehensive social plans to convert cropland to urban uses have little validity. Moreover, it is important to note that, even if the claims of reduced farmland had been substantiated, proponents of social cropland control have not made a convincing case for such action. There are certain circumstances that might call for social land use planning: (1) if farmers are not price conscious, i.e, they are not responsive to current or expected future crop prices since they do not recognize the real value of prime cropland; (2) if farmland prices do not reflect the true value of the product of the land; and (3) if social planners knowledge about future land values is superior to that of current landowners and developers.

Existing evidence does not corroborate the validity of these circumstances. Research clearly indicates that farmers are highly responsive to current and expected future prices. ${ }^{22}$ They sell their land to urban developers because its value is greater if used for urbanization purposes than for cropland (cropland value being determined by the current and expected future prices of the crops grown on it). When the value of land converted to urban use exceeds the value obtained from farming, the farm owner, land developer, and the general public will profit from conversion. ${ }^{13}$ In the absence of harmful neighborhood effects (hidden costs), the costs and benefits of such shifts are carefully assessed by the transacting parties. In other words, the cost to the individual and to society is the foregone value of the land's contribution to farm output. Unless the gain in the new use exceeds the loss, the individuals involved would have no incentive for making the change.

\footnotetext{
${ }^{12}$ See Holbrook Working, "The Theory of Price of Storage," in Selected Writing of Holbrook Working, ed. Dana Kellerman (Board of Trade of the City of Chicago, 1977), pp. 28-30; Marc Nerlove, The Dynamics of Supply: Estimation of Farmers' Response to Price (Baltimore: The John Hopkins Press, 1958 ), pp. 186-235; and Zvi Griliches, "Estimates of the Aggregate U.S. Farm Supply Function," Journal of Farm Economics (May 1960), p. 282-93.

${ }^{13}$ For a discussion, see Nell A. Stevens, "Rising Farmland Prices and Falling Farm Earnings: Is Agriculture in Trouble?" this Review (May 1978), p. 16.
}

The second argument for social planning - that prices alone do not reflect the true value of the product - implies that neighborhood effects are an important factor. Some external costs, such as reduced water quality and impaired landscapes, have been mentioned by the proponents of social control over cropland. However, this argument is subjective because one can easily visualize rural scenes that are quite the opposite of the beautiful landscape ideally depicted by advocates of social control. Cattle feeding pens, swine producing areas, and other livestock facilities are often sources of pollution. In addition, other "unsightly" views associated with farming communities include dilapidated buildings, fences, and equipment dumped along the roadside.

In regard to water quality, most authorities contend that both rural and urban uses may result in water pollution. Those types of pollution that result from farming activities include runoff from livestock habitats and chemicals used for controlling crop diseases, insects, and weeds. Allen Kneese contends that agricultural chemicals present a special (pollutants) problem "as they are delivered to streams in storm runoff from the land and bypass waste treatment plants."14

The third argument for social planning -- that social planners possess superior knowledge compared to that of private individuals - implies that individual farmers and urban land users distribute their resources between the present and the future on a relatively uninformed (of true value) basis. In other words, individual landowners are perceived to be somewhat myopic in assessing the future value of cropland, whereas social land use planners can clearly foresee the "correct" future value of land in its various alternative uses. This argument fails to consider that such vision would provide social planners with amazing opportunities for personal investment gains so that they would not be likely to remain "planners" when they could become wealthy as "doers."

Of even greater importance for the public welfare, however, is the assumption by proponents of social planning that such programs operate in the "public interest" rather than in self-interest. There is little justification for the view that self-interest is eliminated when social groups are given monopoly power over economic functions. As pointed out so cogently by George Stigler, alleged market failures are not evidence that social plamers can provide more services

14Allen V. Kneese, The Economics of Regional Water Qualty Management (Baltimore: The John Hopkins Press, 1964), p. 11 . 
at reduced costs. "We may tell the society to jump out of the market frying pan, but we have no basis for predicting whether it will land in the fire or a luxurious bed." "Is Any impediment to the transfer of crop" land to urban use will increase the cost of land for housing, factories, hospitals, parking, and other uses vital to the public well-being. There is no evidence that social groups can more equitably resolve the conflict between costs and benefits of land use than can private markets.

\section{SUMMARY}

As prime farmland is converted into streets, shopping centers, and residential areas, observers conclude that the quantity of farmland is declining sharply and that this decline should be controlled by social action. Unobserved, however, are the less noticeable but dra-

${ }^{15}$ George F. Stigler, The Citizen and the State (Chicago: The University of Chicago Press, 1975), p. 113. For a further discussion of this problem, see R. H. Coase, "The Problem of Social Cost," The Journal of Law and Economics (October 1960), pp. 1-49; and Roger Leroy Miller, Economics Today (San Francisco: Canfield Press, 1976), pp. 615-23. matic increases in acres of cropland and in production per acre. The number of acres from which crops were harvested rose from the 1969 low point of 286 million to 337 million acres in 1979 . Yields per acre of cropland rose at a 1.1 percent rate from 1910 to 1969 and at a 1.7 percent rate during the period from $1967-69$ to $1977-79$.

As a consequence of the increase in acres harvested and in yields per acre, farm product and food prices have consistently declined relative to other prices, except during the first half of the $1970 \mathrm{~s}$ when export demand rose sharply. Since 1950 , consumers have spent a declining proportion of their disposable personal income on food, even while a larger proportion of domestic farm output was being exported.

Consequently, there is no justification for using social action to preserve cropland as proposed by critics of the current land market system. Furthermore, even if there was some shrinkage in cropland, there is no evidence that the problem can be solved more efficiently by social action than it can be in the market place.

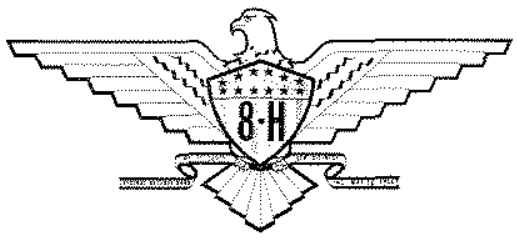

